\title{
Compatibility and characterization of Bio-PE/PCL blends
}

\author{
Elieber Barros Bezerra ${ }^{1}$, Danyelle Campos de França', Dayanne Diniz de Souza Morais', \\ Ingridy Dayane dos Santo Silva², Danilo Diniz Siqueira', Edcleide Maria Araújo ${ }^{1 *}$ (D) and \\ Renate Maria Ramos Wellen²
}

\author{
'Departamento de Engenharia de Materiais, Universidade Federal de Campina Grande - UFCG, \\ Campina Grande, PB, Brasil \\ ${ }^{2}$ Departamento de Engenharia de Materiais, Universidade Federal da Paraíba - UFPB, \\ João Pessoa, PB, Brasil \\ *edcleide.araujo@ufcg.edu.br
}

\begin{abstract}
In this work, blends based on environmentally friend polymers such as Biopolyethylene (Bio-PE), Polycaprolactone (PCL) and Polyethylene graft maleic anhydride (PEgMA) added as compatibilizer agent were produced by conventional extrusion, aiming to produce bio-blends with synergic properties at low processing cost, being at same time non-polluting and therefore contributing to the environment preservation. Differential scanning calorimetry (DSC) showed that blending does not significantly interfere on the melting and crystallization behaviors of neat polymers, suggesting being low miscibility compounds. Mechanical properties were observed changing with blend composition as the impact strength significantly increased reaching values higher than $130 \%$ when compared to neat Bio-PE. Scanning electron microscopy (SEM) images showed honeycomb morphology in Bio-PE/PCL blends, and the addition of PEgMA decreased the coalescence contributing to obtain more stable and synergic compounds. Bio-PE/PCL/PEgMA at 80/20/10 contents presented the best properties and may be used for packaging materials (food containers, film wrapping), and hygiene products.
\end{abstract}

Keywords: Bio-PE, PCL, thermal behavior, mechanical properties, morphology.

How to cite: Bezerra, E. B., França, D. C., Morais, D. D. S., Silva, I. D. S., Siqueira, D. D., Araújo, E. M., \& Wellen, R. M. R. (2019). Compatibility and characterization of Bio-PE/PCL blends. Polímeros: Ciência e Tecnologia, 29(2), e2019022. https://doi.org/10.1590/0104-1428.02518

\section{Introduction}

Currently petroleum-based polymer products are still dominant in the world market due to their excellent mechanical and thermal properties, as well as to their great versatility in several applications, providing an amount of approximately 300 million tons of plastic products produced by the end of this year. However, given the characteristic of nonbiodegradability and durability of some polymers as polyolefins, polyamides, polyesters and so on, a serious environmental problem follows the contemporary man with potential damage to nature, especially in the populous urban centers ${ }^{[1-4]}$.

Therefore, the society has been asking the industrial sector for adopting "ecologically acceptable" policies, such as the rational use of natural resources, mainly in the production of materials for the productive sectors. Focused on this subject polymer scientists have suggested as an alternative to the use of polymers derived from fossil sources the production of biopolymers (polymers produced from renewable sources) and biodegradable (polymers able to naturally degrade in the environment) ones ${ }^{[5-7]}$.

The use of biodegradable polymers appear as a possible and fast solution to reduce environmental pollution, they can be produced from renewable resources such as maize, sugar cane, cellulose and chitin, for instance, additionally they present shorter life cycle compared to the non-biodegradable ones (as polypropylene (PP), poly(ethylene terephthalate) (PET), nylons and so on) and when discarded they produce compounds not harmefull to the environment, as the case of poly(hydroxibutyrate) (PHB), PCL, poly(butylene adipate-co-terephthalate) (PBAT) for instance ${ }^{[7]}$.

Additionally, the use of "green" polymers, such as biopolyethylene (Bio-PE), produced from ethanol (from sugarcane), although not biodegradable, maintains the neutral balance of carbon dioxide $\left(\mathrm{CO}_{2}\right)$ in the natural environment. The $\mathrm{CO}_{2}$ captured from the atmosphere by the biomass, when later released to the atmosphere by the combustion, is captured again by the sugarcane trough the photosynthesis process in the next harvest ${ }^{[7-10]}$.

Another alternative to this scenario would be the use of environmentally degradable polymers, which have the advantage of being stable over their useful life and being degraded in a short time after disposal in the environment; PCL is one of these polymers that has aroused interest in the substitution of conventional polymers since it is a fully biodegradable hydroxycarbonic acid based on polyester. 
Moreover, it has good properties and also compatibility with other materials ${ }^{[11-17]}$.

Research in polymer blends involving these two classes of polymers appears as a viable alternative to the process of developing ecologically friend materials. In addition, studies of polymer blends are an alternative to obtain materials with properties that, in general, are not found in a neat resin ${ }^{[18,19]}$.

Therefore, the objective of this work is to develop polymer blends based on environmentally friend polymers (Bio-PE and PCL) with different compositions; Bio-PE/PCL/PEgMA blends were also produced aiming the tenacification and compatibilization of Bio-PE upon addition of PEgMA, which has PE and MA segments, which are able to react with Bio-PE and PCL end groups. These blends were characterized by differential scanning calorimetry (DSC), heat deflection temperature (HDT), mechanical tensile and impact strength tests, scanning electron microscopy (SEM) and contact angle measurement.

\section{Materials and Methods}

\subsection{Materia/s}

High Density Polyethylene (Bio-PE), I'm green ${ }^{\circledR}$ SHC7260, Braskem. Polymer produced from sugarcane. Minimum carbon content from renewable source of $94 \%$. Density $0.959 \mathrm{~g} / \mathrm{cm}^{3}, \mathrm{MIF}=7.2 \mathrm{~g} / 10 \mathrm{~min}\left(190^{\circ} \mathrm{C} / 2.16 \mathrm{~kg}\right)$. Polycaprolactone (PCL), Capa ${ }^{\circledR} 6500, \mathrm{MIF}=28 \mathrm{~g} / 10 \mathrm{~min}$ $\left(160^{\circ} \mathrm{C} / 2.16 \mathrm{~kg}\right)$ and elongation up to $800 \%$, purchased from Perstorp Winning Formulas. Polyethylene grafted with 1.5-1.7\% Maleic Anhydride (PEgMA) Polybond 3029, purchased from Addivant. Density $0.95 \mathrm{~g} / \mathrm{cm}^{3}$, $\mathrm{MIF}=4.0 \mathrm{~g} / 10 \mathrm{~min}\left(190^{\circ} \mathrm{C} / 2.16 \mathrm{~kg}\right)$ and melt temperature $\left(\mathrm{T}_{\mathrm{m}}\right)=130^{\circ} \mathrm{C}$. These parameters were collected from the resin datasheets, which are inserted in Appendix 1 with HDPE, PCL and PE-gMA Datasheets, respectively.

\subsection{Methods}

Polymer blending carried out in a modular, interpenetrating, twin screw extruder with L/D ratio of 40, model ZSK $18 \mathrm{~mm}$, Werner-Pfleiderer, Coperion (Wesseling, Rhein-Erft-Kreis, Germany). Prior to extrusion, the raw materials were manually mixed to promote further homogenization. For all blends, the following extrusion parameters were used: feed rate of $5 \mathrm{~kg} / \mathrm{h}$; screw speed of $250 \mathrm{rpm}$; temperature profile in the extruder zones $200^{\circ} \mathrm{C}$ in all zones. The output material was granulated and oven dried under vacuum at $40^{\circ} \mathrm{C}$ for $24 \mathrm{~h}$.

The compositions of the extruded blends and their codes are shown in Table 1.

Figure 1 shows the screw used during the extrusion. The screw configuration has mixing sections with dispersive and distributive elements. The main feed zone of premixed materials is indicated in Figure 1 with the down arrow. The upward-facing arrows are degassing points (vents).

After extrusion, injected specimens were molded according to ASTM standards D 638, D256 and D648, for tensile, impact and HDT experiments, respectively. An Arburg Injector, Model Allrounder 270C Golden Edition (Loßburg, Baden-Württemberg, Germany), was used, operating at $180^{\circ} \mathrm{C}$, with mold at $20^{\circ} \mathrm{C}$. Blends, neat Bio-PE and PCL were subjected to the same injection parameters. An average of 10 specimens was used for each investigated composition.

\subsection{Characterizations}

\subsubsection{Differential Scanning Calorimetry (DSC)}

DSC analyzes were performed using a TA Instrument DSC-Q20 (New Castle, Delawere, EUA). The temperature program used was: heating from $20^{\circ} \mathrm{C}$ to $250^{\circ} \mathrm{C}$, cooling to $10^{\circ} \mathrm{C}$, reheating to $250^{\circ} \mathrm{C}$, at a heating/cooling rate of $10^{\circ} \mathrm{C} / \mathrm{min}$, under inert environment with nitrogen flow of $50 \mathrm{~mL} / \mathrm{min}$. The samples tested weighed approximately $3.5 \mathrm{mg}$.

\subsubsection{Heat Deflection Temperature (HDT)}

HDT was determined according to ASTM D 648, in a Ceast equipment (Norwood, Massachusetts, EUA), model HDT 6 VICAT/N 6921.000, with a tension of $455 \mathrm{kPa}$, heating rate of $120^{\circ} \mathrm{C} / \mathrm{h}(\operatorname{method} \mathrm{A})$. The temperature was determined after the sample deflecting $0.25 \mathrm{~mm}$. Series of five injected samples were tested and the HDT, with its respective standard deviation, is reported.

\subsubsection{Mechanical test}

The tensile tests were performed according to ASTM D 638. Properties as elastic modulus, tensile strength and elongation at break were measured. The tests were performed in a universal EMIC equipment (Curitiba, Paraná, Brazil), model DL10000, using a $100 \mathrm{kgf}$ load cell, with deformation rate of $50 \mathrm{~mm} / \mathrm{min}$, operating at room temperature $\left(\sim 23^{\circ} \mathrm{C}\right)$. The results presented are an average of 10 specimens tested.

Table 1. Compositions of Bio-PE, PCL, Bio-PE/PCL and Bio-PE/ PCL/PEgMA blends.

\begin{tabular}{lccc}
\hline \multicolumn{1}{c}{ Compounds } & Bio-PE (\%) & PCL (\%) & PEgMA (phr) \\
\hline Bio-PE & 100 & - & - \\
Bio-PE/PCL & 90 & 10 & - \\
Bio-PE/PCL/PEgMA & 90 & 10 & 10 \\
Bio-PE/PCL & 80 & 20 & - \\
Bio-PE/PCL/PEgMA & 80 & 20 & 10 \\
Bio-PE/PCL & 70 & 30 & - \\
Bio-PE/PCL/PEgMA & 70 & 30 & 10 \\
PCL & - & 100 & - \\
\hline
\end{tabular}

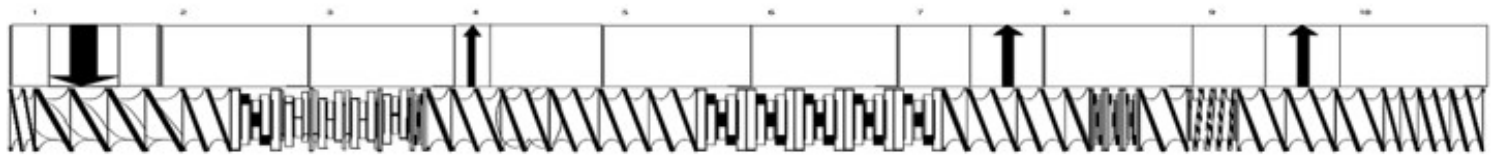

Figure 1. Schematic representation of the screw configuration used during the extrusion. 


\subsubsection{Mechanical impact strength test}

The IZOD impact strength tests were performed on notched specimens, using a Resil 5.5 equipment from Ceast (Norwood, Massachusetts, EUA) and a pendulum of $2.75 \mathrm{~J}$, according to ASTM D 256, at room temperature $\left(\sim 23^{\circ} \mathrm{C}\right)$. The results reported were obtained from an average of 10 specimens.

\subsubsection{Scanning Electron Microscopy (SEM)}

SEM analyzes were obtained on the Tescan Vega 3 equipment (South Moravia, Brno, Czech Republic) with a voltage of $30 \mathrm{kV}$ under high vacuum, images were captured on the fracture surface of the fractured impact specimen. The fracture surfaces of the samples were gold-covered (Shimadzu Metallic-IC-50, using a current of $4 \mathrm{~mA}$ for a period of 3 minutes) in order to avoid negative charge accumulation. The average diameters of dispersed phases were computed using the Tesca See 3 software.

\subsubsection{Contact angle measurement}

The contact angle analysis to determine the hydrophilicity of the blends was performed by distilled water drop method through a Phoenix-i model of the Electro Optics - SEO Surface (Saneop-ro, Namwon, South Korea). This analysis was done on the surface of the injection molded specimens. An analysis was performed from 20 photos, using an interval of 10 seconds, totaling 200s.

\section{Results and Discussions}

\subsection{Differential Scanning Calorimetry (DSC)}

Understanding how the addition of PCL and PEgMA affect the morphology of Bio-PE is especially important because the resulting crystalline structure will influence the chemical as well as physical properties of the blends; to reach this aim DSC was employed, these scans are presented in Figure 2, and parameters determined from them are presented in Tables A1-A4 of Appendix 2 .

DSC scans of Figure 2 (Top) present the exothermic peaks relative to melt crystallization of Bio-PE and PCL. The addition of PCL slightly changed the crystallization of Bio-PE, which has a crystallization range between $106.04^{\circ} \mathrm{C}$ and $119.19^{\circ} \mathrm{C}$; the exothermic crystallization peak of PCL in the blends was observed between 32.91 and $42.48^{\circ} \mathrm{C}$. Bio-PE has a degree of crystallinity $\Delta \mathrm{X} \sim 14.50 \%$ and PCL between $4.75-8.65 \%$; these data are in the literature range as published by Fel et al. ${ }^{[20]}$ for (high density polyethylene) HDPE and by Antunes \& Felisberti ${ }^{[21]}$ for PCL. The crystallization rates and $\tau_{1 / 2}$ (time to reach $50 \%$ of crystallinity) of Bio-PE and PCL were subtly modified in the blends, as shown in Figures A4 and A5. These behaviors suggest the low miscibility of Bio-PE/PCL system, with respective crystalline phases, i.e. Bio-PE and PCL, crystallizing as separate phases, nevertheless phase segregation was not verified as further on presented in SEM images (Figure 3) where Bio-PE is the matrix and PCL the dispersed phase, nevertheless
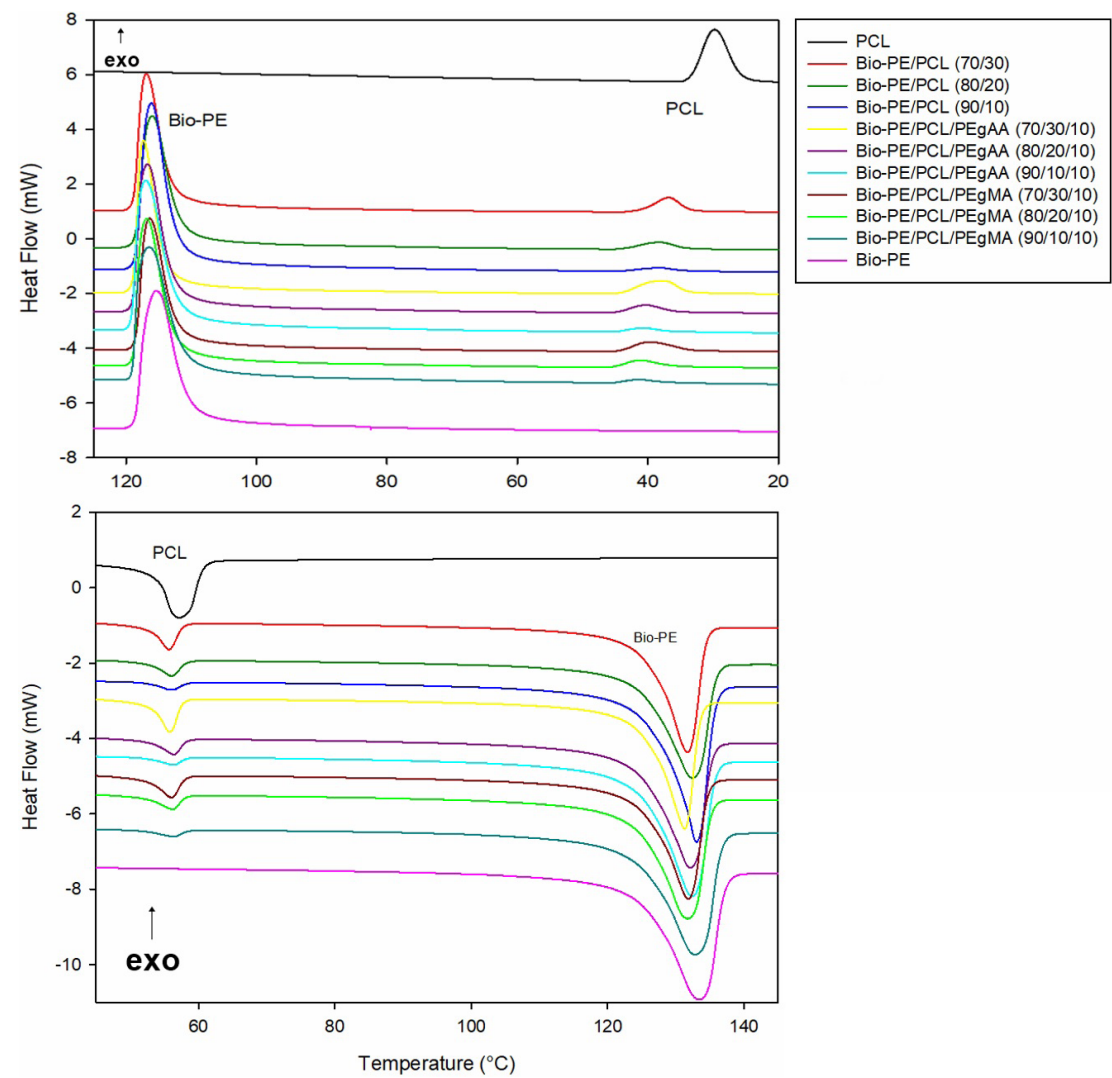

Figure 2. Top: DSC scans of Bio-PE, PCL, Bio-PE/PCL and Bio-PE/PCL/PEgMA compounds acquired during cooling. Bottom: DSC scans of Bio-PE, PCL, Bio-PE/PCL and Bio-PE/PCL/PEgMA compounds acquired during the second heating. 
Bezerra, E. B., França, D. C., Morais, D. D. S., Silva, I. D. S., Siqueira, D. D., Araújo, E. M., \& Wellen, R. M. R.

upon addition of PEgMA the particle sizes decreased as an indication of chemical interactions between Bio-PE/PCL and PEgMA, conducting to the blends compatibilization ${ }^{[22]}$.

DSC scans acquired during the second heating are presented in Figure 2 (bottom), two endothermic peaks are observed, in the lower temperature region $47.57-62.05^{\circ} \mathrm{C}$ and in higher temperatures $106.41-138.46^{\circ} \mathrm{C}$, associate with the fusion of PCL and Bio-PE, respectively. Similarly to that observed during the melt crystallization, the melting behavior of Bio-PE was not altered in the blends, with the

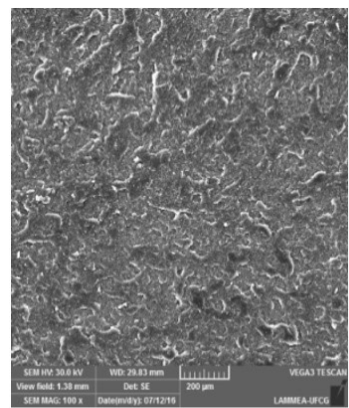

(a) $100 \mathrm{x}$

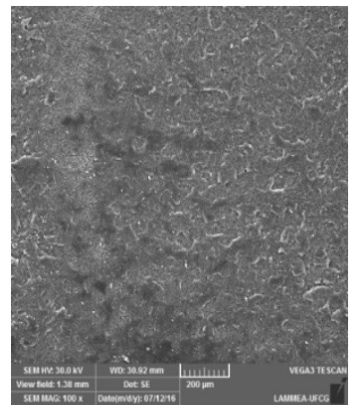

(e) $100 \mathrm{x}$

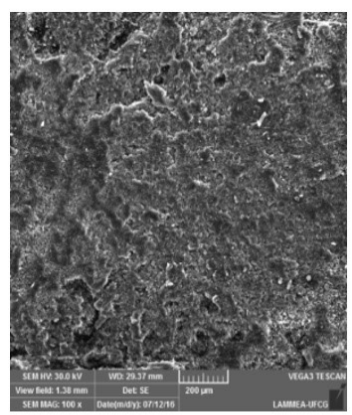

(i) $100 \mathrm{x}$

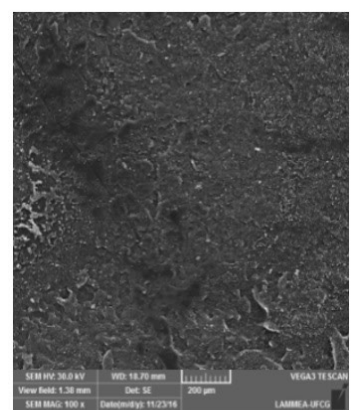

(m) $100 x$

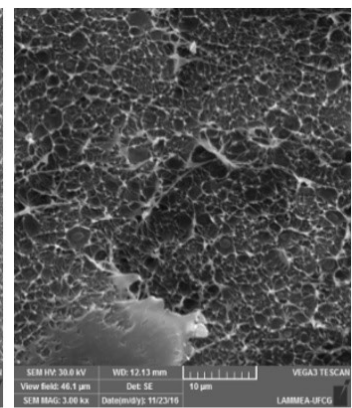

(b) $3000 x$

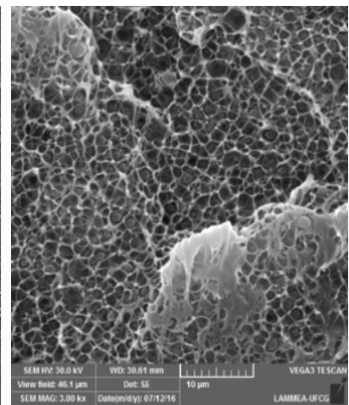

(f) $3000 x$

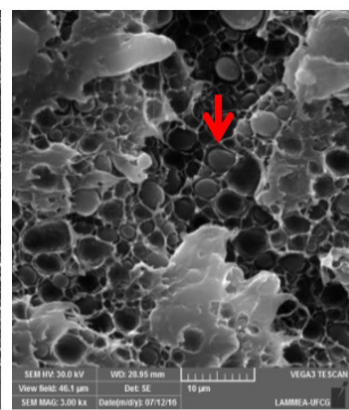

(j) $3000 x$

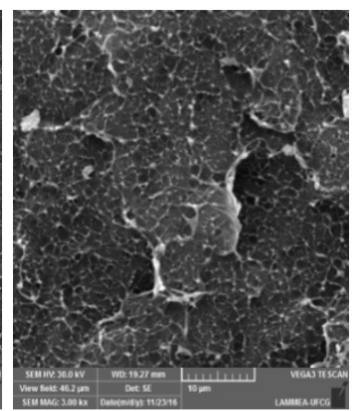

(n) $3000 \mathrm{x}$

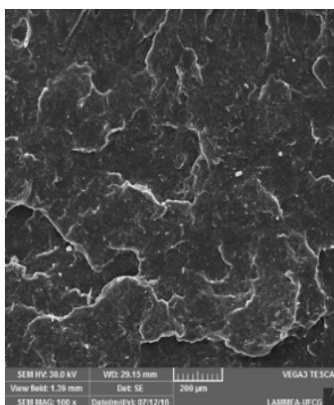

(c) $100 \mathrm{x}$

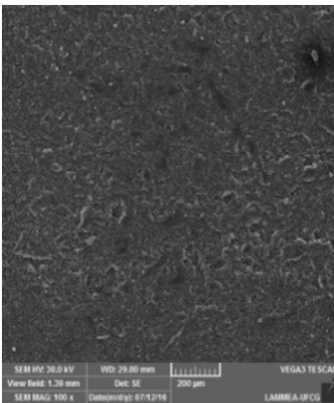

(g) $100 x$

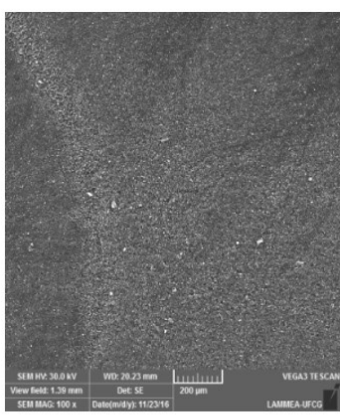

(k) $100 \mathrm{x}$

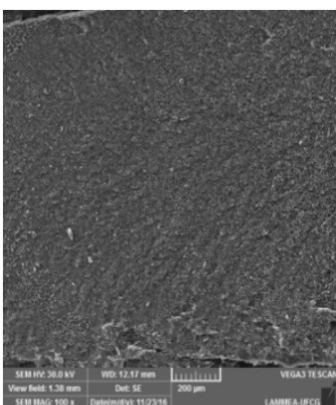

(o) $100 \mathrm{x}$

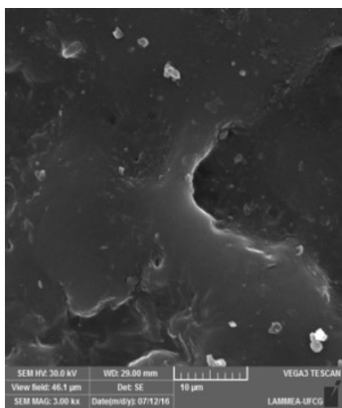

(d) $3000 \mathrm{x}$

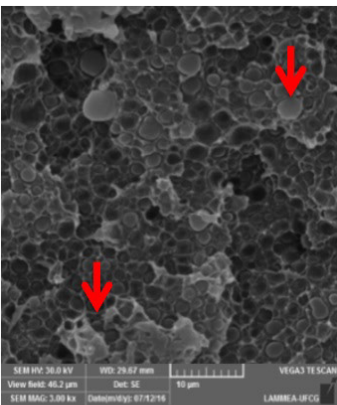

(h) $3000 \mathrm{x}$

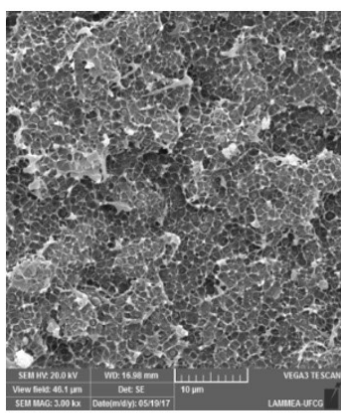

(1) $3000 \mathrm{x}$

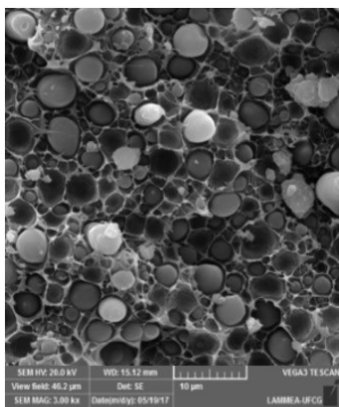

(p) $3000 x$

Figure 3. SEM images of fractured surface of: Bio-PE (a, b); PCL (c, d); Bio-PE/PCL (90/10) (e, f); Bio-PE/PCL (80/20) (g, h); Bio-PE/PCL (70/30) (i, j); Bio-PE/PCL/PEgMA (90/10/10 phr) (k, 1); PE/PCL/PEgMA (80/20/10 phr) (m, n); PE/PCL/PEgMA (70/30/10 phr) (o, p). 
degree of crystallinity $\Delta \mathrm{X}_{\mathrm{c}}: 13.27-18.28 \%$. The parameters computed from these scans are found in Tables A1-A4 and in Figures A6 and A7 of Appendix 2 and 3.

The Molten Fraction plots presented a sigmoidal shape characteristic of phase transformation in polymers without discontinuities, behavior similar to that observed during crystallization from the melt (Relative Crystallinity); these curves are presented in Appendix 3, Figures A8-A11. The melting rates of $\mathrm{PCL}$ and Bio-PE increased in the blends with values between $30-50 \%$ higher than in the neat resins, which can be understood as a facilitated melting process, thus providing a processing with less energy consuming and possibly cheaper ${ }^{[23,24]}$.

\subsection{Heat Deflection Temperature (HDT)}

Table 2 shows HDT of Bio-PE, Bio-PE/PCL and Bio-PE/PCL/PEgMA blends. Addition of PCL to Bio-PE promoted a slight decrease in the HDT of Bio-PE/PCL blends, being a reduction of approximately $3.9 \%$ for Bio-PE/PCL blend (90/10); $9.3 \%$ for $80 / 20$ and $12.6 \%$ for $70 / 30$ blend. This decrease is most like due to the high flexibility, low melting temperature $\left(\approx 60^{\circ} \mathrm{C}\right)$ and low glass transition $\left(\approx-60^{\circ} \mathrm{C}\right)$ of $\mathrm{PCL}^{[25]}$. These results are in agreement with the data obtained by DSC.

The addition of PEgMA to Bio-PE/PCL provided distinct results for the different concentrations of PCL. It is verified for Bio-PE/PCL/PEgMA (90/10/10 phr and $70 / 30 / 10 \mathrm{phr}$ ) a similar behavior to that presented by their respective binary blends. For the compound 80/20/10 phr, an increase in HDT compared to Bio-PE is observed, this increase being approximately $3.4 \%$, results suggest in this concentration the effect of PEgMA is optimized in terms of higher heat deflexion temperature stability.

Table 2. Heat deflection temperature (HDT) of Bio-PE, PCL, Bio-PE/PCL and Bio-PE/PCL/PEgMA blends.

\begin{tabular}{lc}
\hline \multicolumn{1}{c}{ Composition } & HDT $\left({ }^{\circ} \mathbf{C}\right)$ \\
\hline Bio-PE & $66.8 \pm 1.5$ \\
Bio-PE/PCL (90/10) & $64.2 \pm 0.7$ \\
Bio-PE/PCL/PEgMA (90/10/10 phr) & $64.5 \pm 0.4$ \\
Bio-PE/PCL (80/20) & $60.6 \pm 1.0$ \\
Bio-PE/PCL/PEgMA (80/20/10 phr) & $69.1 \pm 0.2$ \\
Bio-PE/PCL (70/30) & $58.4 \pm 0.5$ \\
Bio-PE/PCL/PEgMA (70/30/10 phr) & $58.9 \pm 0.8$ \\
PCL & $51.3 \pm 0.7$ \\
\hline
\end{tabular}

In general, the individual contribution of each component and the morphology generated by the phases in polymer blends are the most important characteristics concerned with its performance. Generally, the continuous phase provides greater contribution to the HDT of the blends, as also reported by Ferreira et al. ${ }^{[26]}$ and Luna et al. ${ }^{[27]}$. Subsequently, the morphology of blends will be examined by SEM, where these results can be better elucidated.

\subsection{Mechanical tests - tensile strength}

Table 3 presents the results for Elastic Modulus, Tensile Strength and Elongation at Break of the investigated compounds in this work.

From the data shown in Table 3, it is possible to infer that Bio-PE and PCL have high elongation at break, that is, both are able of undergoing large deformations ${ }^{[28,29]}$.

Analyzing the effect of PCL addition on Bio-PE/PCL blends, it was observed that increasing PCL content did not promote a significant change in the Elastic Modulus nor in the Tensile Strength data. In general, the stiffness of immiscible blends may be related with the competitive effect between the performance of the interface and the stiff polymer content that presents higher stiffness (modulus), as reported by Machado et al. ${ }^{[30]}$, Rosa et al. ${ }^{[31]}$, Moura et al. ${ }^{[32]}$ and Silva $^{[33]}$. In the present work, despite the fact the Bio-PE/PCL blends are immiscible, their mechanical behavior was not negatively affected, by the contrary, the Elastic Modulus of Bio-PE/PCL was observed being 5\% higher than neat Bio-PE, producing a synergic performance.

In relation to the addition of PEgMA, it did not result in higher changes in the Elastic Modulus with observed decreases between $8-15 \%$, on the other hand, the Elongation at Break of Bio-PE/PCL/PEgMA blends showed increases higher than $70 \%$ in relation to Bio-PE/PCL blends. These results are linked to the morphological effect among the phases, despite the immiscible character (as observed by DSC scans Figure 2, SEM images Figure 3, Table A1-A4 and Figures A6-A7 of Appendix 2 and 3), in the amorphous phases of both polymers, secondary interactions are possible to occur, additionally PEgMA contributes to better mechanical performance. SEM images captured with the aim of a better enlightenment, and shown further on ${ }^{[30,33,34]}$, suggest the Elongation at Break of Bio-PE/PCL blends, being the ternary systems with addition of the functionalized copolymer PEgMA improved (higher), which can be resulted from the reaction between maleic anhydride with the hydroxyl $(\mathrm{OH})$

Table 3. Tensile properties of Bio-PE, PCL, Bio-PE/PCL and Bio-PE/PCL/PEgMA blends.

\begin{tabular}{|c|c|c|c|}
\hline Composition & Elastic modulus (MPa) & Tensile strength (MPa) & Elongation at break (\%) \\
\hline Bio-PE & $445.2 \pm 20.3$ & $22.9 \pm 0.4$ & $531.3 \pm 26.6$ \\
\hline Bio-PE/PCL (90/10) & $467.6 \pm 15.9$ & $23.6 \pm 0.3$ & $252.5 \pm 20.6$ \\
\hline Bio-PE/PCL/PEgMA (90/10/10 phr) & $412.8 \pm 11.9$ & $23.2 \pm 0.4$ & $425.9 \pm 34.6$ \\
\hline Bio-PE/PCL (80/20) & $465.4 \pm 6.9$ & $23.7 \pm 0.3$ & Not determined* \\
\hline Bio-PE/PCL/PEgMA (80/20/10 phr) & $430.8 \pm 10.1$ & $23.0 \pm 0.5$ & $475.1 \pm 15.4$ \\
\hline Bio-PE/PCL (70/30) & $426.2 \pm 6.6$ & $23.3 \pm 0.2$ & $13.8 \pm 0.9$ \\
\hline Bio-PE/PCL/PEgMA (70/30/10 phr) & $365.3 \pm 10.1$ & $21.5 \pm 0.2$ & Not determined* \\
\hline PCL & $238.5 \pm 16.5$ & $18.8 \pm 0.3$ & $>580^{* *}$ \\
\hline
\end{tabular}

*After cold drawing and neck propagation, the specimens showed formation of fibrils and the equipment was unable to record the rupture;

**Specimen did not break during the test. 
end groups of PCL that may be taken place providing an interface with higher performance, behaviors which can be inferred from decreases in dispersed phase as showed in Figure 3 and Table 4 by dispersed phase's average diameter measurements ${ }^{[24,25,35-40]}$.

\subsection{Impact strength}

Table 5 shows the Impact Strength results of Bio-PE, PCL, Bio-PE/PCL and Bio-PE/PCL/PEgMA blends. It is verified that addition of $10 \%$ PCL did not promote a significant variation in the impact strength of Bio-PE. On the other hand, blends with $20 \%$ and 30\% PCL showed higher impact strength with increases of $88.2 \%$ for Bio-PE/PCL (80/20) and $83.2 \%$ for Bio-PE/PCL (70/30). This increase may be related to the PCL effect that presents elastomeric characteristics, being able to act as a properly impact modifier, thus promoting a significant improvement in the energy absorption mechanisms of the produced blends in this work $^{[33,38,41]}$. The addition of PEgMA also contributed to increase the impact strength, where increases of $133.2 \%$ for Bio-PE/PCL/PEgMA (80/20/10 phr) and 100.3\% for Bio-PE/PCL/PEgMA (70/30/10 phr) were reached. This behavior can be attributed to the higher amount of linkages between Bio-PE/PCL phases promoted by the reaction trough maleic anhydride and hydroxyl groups of PCL, as well as the compatibility of PEgMA with Bio-PE, which efficiently drives the tension transfer mechanisms between the phases (Bio-PE matrix and PCL dispersed phase, see SEM images $)^{[24,33,38]}$.

\subsection{Scanning Electron Microscopy (SEM)}

Figure 3 presents SEM images of Bio-PE, PCL and Bio-PE/PCL and Bio-PE/PCL/PEgMA blends, these images were captured on the fractured surface of the specimens after impact experiments.

In Figure 3a-d is observed the surfaces of Bio-PE and PCL with characteristics of ductile fracture evidencing the elastic deformation followed by the plastic one, these images corroborate the previous results obtained with mechanical

Table 4. Average diameter for the dispersed phase of Bio-PE/PCL blends.

\begin{tabular}{cc}
\hline Composition & Average Diameter $(\boldsymbol{\mu m})$ \\
\hline Bio-PE/PCL $(90 / 10)$ & $1.2 \pm 0.1$ \\
Bio-PE/PCL (80/20) & $2.0 \pm 0.1$ \\
Bio-PE/PCL (70/30) & $2.8 \pm 0.2$ \\
\hline
\end{tabular}

Table 5. Impact Strength of Bio-PE, PCL, Bio-PE/PCL and Bio-PE/PCL/PEgMA blends.

\begin{tabular}{lc}
\multicolumn{1}{c}{ Composition } & Impact strength (J/m) \\
\hline Bio-PE & $34.0 \pm 1.0$ \\
Bio-PE/PCL (90/10) & $36.5 \pm 3.1$ \\
Bio-PE/PCL/PEgMA (90/10/10 phr) & $36.0 \pm 1.9$ \\
Bio-PE/PCL (80/20) & $64.0 \pm 2.9$ \\
Bio-PE/PCL/PEgMA (80/20/10 phr) & $79.3 \pm 2.8$ \\
Bio-PE/PCL (70/30) & $62.3 \pm 3.8$ \\
Bio-PE/PCL/PEgMA (70/30/10 phr) & $68.1 \pm 5.0$ \\
PCL & $178.5 \pm 4.4$ \\
\hline
\end{tabular}

tests where deformations higher than 500\% were reached for the neat polymers.

SEM images of 90/10, 80/20 and 70/30 Bio-PE/PCL blends, respectively, are shown in Figure $3 \mathrm{e}-\mathrm{j}$. These SEMs present a honeycomb morphology ${ }^{[42]}$, and suggest low interfacial adhesion.

The increase of PCL content into Bio-PE/PCL blends conducted to an increase in the mean diameter of the dispersed phase, (see results in Table 4), leading to the coalescence between PCL domains, which are indicated by the red arrows in Figure 3. In addition, a larger number of PCL domains in Bio-PE/PCL 70/30 were pull out from Bio-PE matrix ${ }^{[43,44]}$, these results agree with those shown in the DSC analyzes and with mechanical properties, where low miscibility was observed.

The effect of PEgMA on the phase behavior of Bio-PE/PCL blends is also shown in Figure $3 \mathrm{k}-\mathrm{p}$. For Bio-PE/PCL/PEgMA 90/10/10 and 80/20/10 blends is verified a very similar morphology to that of Bio-PE. These images show a homogeneous morphology, and it is difficult to make distinction between the dispersed PCL phase from the Bio-PE matrix. This effect may occur due to the interaction and ability of the compatibillizer (PEgMA) to remain at the interface, promoting a reduction of the interfacial energy and avoiding the domain coalescence, this would be the driving force for the improvement in the impact strength as well as for the increase in the elongation at break as previously presented in mechanical results ${ }^{[45,46]}$.

For the Bio-PE/PCL/PEgMa 70/30/10 blend, Figure 3o, p is observed a morphology similar to that of Bio-PE/PCL $70 / 30$ blend. However, a smaller amount of domains are verified on the fracture surface in relation to the binary blend. At this concentration, the compatibillizer was shown to be less effective compared to the compositions Bio-PE/PCL/PEgMA 90/10/10 and 80/20/10. As also presented in Table 4 the dispersed phase's average dimater increases with PCL content in binary blends and decreases upon addition of PEgMA, trend observed for Bio-PE/PCL $90 / 10 / 10$ and $80 / 20 / 10$, for the blend $70 / 30 / 10$ the trend change and coalescence increases, suggesting solubility limit barrier was reached.

Summing up, the incorporation of PEgMA provided a better adhesion between the phases, contributing to the homogeneity of the blends in relation to the non-compatibillized ones, i.e., PEgMA led to the morphology stabilization of the blends ${ }^{[32,44,46,47]}$. It is suggested the addition of PEgMA increases interfacial adhesion due to the chemical interaction between the hydroxyl group of PCL and the maleic anhydride groups, as previously reported by Bezerra et al. ${ }^{[24]}$.

\subsection{Contact angle}

The contact angle measurement allows evaluating the hydrophilicity and hydrophobicity of the polymer blend surfaces, where this means the interaction energy between the surface and the used liquid. The collected data for the contact angle demonstrates the increased degree of blend surface interaction with water, indicating an increase in its hydrophilic character with the increase of PCL content, which is expected since PCL is the most hydrophilic polymer ${ }^{[48-50]}$. 


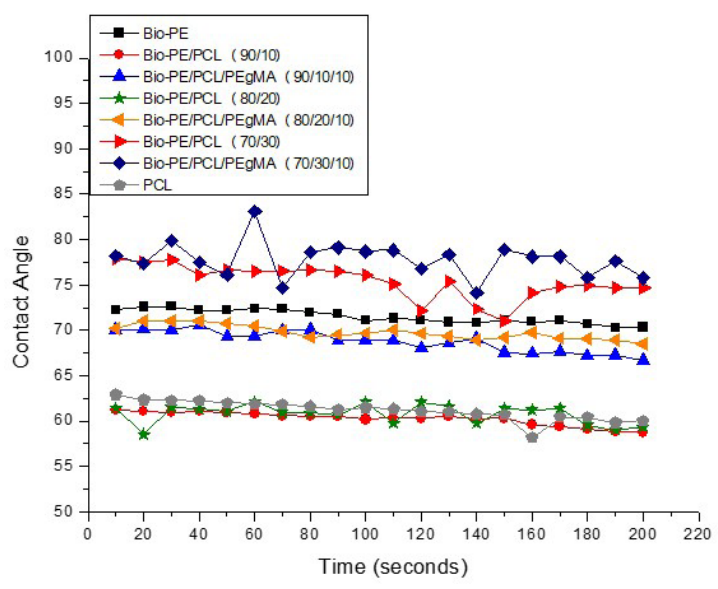

Figure 4. Contact angle of Bio-PE, PCL, Bio-PE/PCL and Bio-PE/PCL/PEgMA blends.

Figure 4 shows the data of contact angle for Bio-PE, PCL, Bio-PE/PCL and Bio-PE/PCL/PEgMA blends, at different times, and Table A5 (Appendix 4) presents the average data with the standard deviation included. For the Bio-PE/PCL blends with $10 \%$ and $20 \%$ of PCL the contact angle is observed reducing $15.7 \%$ and $15 \%$, respectively. For Bio-PE/PCL blend (70/30) the contact angle increased $5.5 \%$ related to Bio-PE, as previously observed in Figure 3 and Table 4 at this composition coalescence of PCL dispersed particles took place decreasing the contact area of PCL phase and possibly providing a lower contact angle as presented in Figure 4.

For Bio-PE/PCL/PEgMA blends, i.e., 90/10/10 and $80 / 20 / 10$, it was observed that addition of PEgMA promoted stabilization of the contact angle; meanwhile an increase of this parameter was verified for the composition 70/30/10. As previously reported, this is probably due to the occurrence of reactions between the maleic anhydride group and hydroxyl groups of PCL, decreasing the disperse particle size and improving the the system compatilization ${ }^{[24]}$.

\section{Conclusions}

Processing of Bio-PE/PCL and Bio-PE/PCL/PEgMA blends does lightly interfere in the crystallization and melting events of neat polymers suggesting being mixtures with low miscibility. From HDT data reduced values were observed for the binary blends, meanwhile PEgMA provided subtle increase. Contact angle measurements indicate an increase in the blend's hydrophilic character increasing PCL content. Addition of PCL to Bio-PE reduced the elastic modulus, increased the elongation at break and impact strength, allowing a control of these properties by changing the blend composition. Impact Strength of compatibilized blends significantly increased when compared to neat Bio-PE being $113.2 \%$ higher for Bio-PE/PCL/PEgMA. Addition of PEgMA decreases the phase coalescence conducting to a more stable compounds as evidenced by SEM images. Summing up Bio-PE/PCL/PEgMA (80/20/10) is thermally stable presenting better homogeneity with higher HDT and Impact strength.

\section{Acknowledgements}

The authors thank Addivant for the functionalized copolymers; Labmat (Laboratory of Materials Engineering/CCT/UFCG) for experiments, to MCTI/CNPq, CAPES/PNPD and CAPES, for the financial support.

\section{References}

1. Hemais, C. A., Rosa, E. O. R., \& Barros, H. M. (2000). Observações sobre o desenvolvimento tecnológico e os ciclos da indústria de polímeros no Brasil. Polímeros: Ciência e Tecnologia, 10(3), 149-154. http://dx.doi.org/10.1590/S010414282000000300011

2. Rosa, D. S., Franco, B. L. M., \& Calil, M. R. (2001). Biodegradabilidade e propriedades mecânicas de novas misturas poliméricas. Polímeros: Ciência e Tecnologia, 11(2), 82-88. http://dx.doi.org/10.1590/S0104-14282001000200010.

3. Rosa, D. S., Chui, Q. S. H., Pantano, R., Fo., \& Agnelli, J. A. M. (2002). Avaliação da biodegradação de Poli- $\beta$-(Hidroxibutirato), Poli- $\beta$-(Hidroxibutirato-co-valerato) e Poli- $\varepsilon$-(caprolactona) em solo compostado. Polímeros: Ciência e Tecnologia, 12(4), 311-317. http://dx.doi.org/10.1590/S0104-14282002000400015.

4. Le Guern, C. (2018). When the mermaids cry: the great plastic tide. Natural Care. Retrieved in 2018, October 20, from http:// plastic-pollution.org

5. Ray, S. S., \& Bousmina, M. (2005). Biodegradable polymers and their layered silicate nanocomposites: in greening the 21st century materials world. Progress in Materials Science, 50(8), 962-1079. http://dx.doi.org/10.1016/j.pmatsci.2005.05.002.

6. Brito, G. F., Agrawal, P., Araújo, E. M., \& Mélo, T. J. A. (2012). Tenacificação do Poli(Ácido Lático) pela adição do terpolímero (Etileno/Acrilato de Metila/Metacrilato de Glicidila). Polímeros: Ciência e Tecnologia, 22(2), 164-169. http://dx.doi.org/10.1590/S0104-14282012005000025.

7. Bastioli, C. (2005). Handbook of biodegradable polymers. Shrewsbury: Rapra Technology.

8. Associação Brasileira de Normas Técnicas. (2008). NBR 15448-1: embalagens plásticas degradáveis e/ou de fontes renováveis - parte 1: Terminologia. Rio de Janeiro: ABNT.

9. Brito, G. F., Agrawal, P., Araújo, E. M., \& Mélo, T. J. A. (2012). Polylactide/Biopolyethylene bioblends. Polímeros: Ciência e Tecnologia, 22(5), 427-429. http://dx.doi.org/10.1590/S010414282012005000072.

10. Braskem Produtos Verdes. Retrieved in 2018, March 19, from http://www.braskem.com/site.aspx/FAQ_PeVerde

11. Swift, G. (1998). Requirements for biodegradable water-soluble polymers. Polymer Degradation \& Stability, 59(1-3), 19-24. http://dx.doi.org/10.1016/S0141-3910(97)00162-6.

12. Braunegg, G., Lefebvre, G., \& Genser, K. F. (1998). Polyhydroxyalkanoates, biopolyesters from renewable resources: physiological and engineering aspects. Journal of Biotechnology, 65(2-3), 27-61. http://dx.doi.org/10.1016/ S0168-1656(98)00126-6. PMid:9828458.

13. Zuchowska, O., Hlavata, D., Steller, R., Adamiak, W., \& Meissner, W. (1999). Physical structure of polyolefin-starch blends after ageing. Polymer Degradation \& Stability, 64(2), 339-346. http://dx.doi.org/10.1016/S0141-3910(98)00212-2.

14. Pelicano, M., Pachekoski, W., \& Agnelli, J. A. M. (2009). Influência da adição de amido de mandioca na biodegradação da blenda polimérica PHBV/Ecoflex. Polimeros: Ciência e Tecnologia, 19(3), 212-217. http://dx.doi.org/10.1590/S010414282009000300009 .

15. American Society For Testing and Materials. (2017). ASTM D883: terminology relating to plastics. West Conshohocken: Philadelphia. 
16. Amini, M., Mobli, M., Khalili, M., \& Ebadi-Dehaghani, H. (2018). Assessment of compatibility in Polypropylene/ Poly(lactic acid)/Ethylene vinyl alcohol ternary blends: relating experiments and molecular dynamics simulation results. Journal of Macromolecular Science, Part B: Physics, 57(4), 1-18. http://dx.doi.org/10.1080/00222348.2018.1460153.

17. Boronat, T., Fombuena, V., Garcia-Sanoguera, D., SanchezNacher, L., \& Balart, R. (2015). Development of a biocomposite based on green polyethylene biopolymer and eggshell. Materials \& Design, 68, 177-185. http://dx.doi.org/10.1016/j. matdes.2014.12.027.

18. Utracki, L. A. (2002). Polymer blends handbook (Vol. 1). Netherlands: Kluwer Academic Publishers.

19. Matta, A. K., Rao, R. U., Suman, K. N. S., \& Rambabu, V. (2014). Preparation and characterization of biodegradable PLA/PCL polymeric blends. Procedia Materials Science, 6, 1266-1270. http://dx.doi.org/10.1016/j.mspro.2014.07.201.

20. Fel, E., Khrouz, L., Massardier, V., Cassagnau, P., \& Bonneviot, L. (2016). Comparative study of gamma-irradiated PP and PE polyolefins part 2: Properties of PP/PE blends obtained by reactive processing with radicals obtained by high shear or gamma-irradiation. Polymer, 82, 217-227. http://dx.doi. org/10.1016/j.polymer.2015.10.070.

21. Antunes, M. C. M., \& Felisberti, M. I. (2005). Blends of Poly(hydroxybutyrate) and Poly ( $\varepsilon$-caprolactone) Obtained from Melting Mixture. Polímeros: Ciência e Tecnologia, 15(2), 134-138. http://dx.doi.org/10.1590/S0104-14282005000200014.

22. Faker, M., Razavi Aghjeh, M. K., Ghaffari, M., \& Seyyedi, S. A. (2008). Rheology, morphology and mechanical properties of polyethylene/ethylene vinyl acetate copolymer (PE/EVA) blends. European Polymer Journal, 44(6), 1834-1842. http:// dx.doi.org/10.1016/j.eurpolymj.2008.04.002.

23. Greco, R., Mancarella, C., Martuscelli, E., Ragosta, G., \& Yin, J. (1987). Polyolefin blends: 1. Effect of EPR composition on structure, morphology and mechanical properties of HDPE/ EPR alloys. Polymer, 28(11), 1922-1928. http://dx.doi. org/10.1016/0032-3861(87)90301-6.

24. Bezerra, E. B., França, D. C., Morais, D. D. S., Ferreira, E. S. B., Araújo, E. M., \& Wellen, R. M. R. (2017). Comportamento reológico do Bio-PE e do PCL na presença do PEgAA e PEgMA. Revista Matéria, 22(1), 1-12. http://dx.doi.org/10.1590/s1517707620170001.0130 .

25. Morais, D. D. S. (2016). Desenvolvimento de blendas de Poliestireno/Poli(e-caprolactona) (Tese de doutorado). Universidade Federal de Campina Grande, Campina Grande.

26. Ferreira, L. A. S., Pessan, L. A., \& Hage, E., Jr. (1997). Comportamento mecânico e termo-mecânico de blendas poliméricas PBT/ABS. Polímeros: Ciência e Tecnologia, 7(1), 67-72. http://dx.doi.org/10.1590/S0104-14281997000100011.

27. Luna, C. B. B., Silva, D. F., \& Araújo, E. M. (2014). Estudo do comportamento de blendas de poliamida 6/resíduo de borracha da indústria de calçados. Revista Univap, 20(36), 98-110. http://dx.doi.org/10.18066/revunivap.v20i36.249.

28. Boronat, T., Fombuena, V., Garcia-Sanoguera, D., SanchezNacher, L., \& Balart, R. (2015). Development of a biocomposite based on green polyethylene biopolymer and eggshell. Materials \& Design, 68, 177-185. http://dx.doi.org/10.1016/j. matdes.2014.12.027.

29. Escocio, V. A., Visconte, L. L. Y., Cavalcante, A. P., Furatado, A. M. S., \& Pacheco, E. B. A. V. (2015) Study of mechanical and morphological properties of biobased polyethylene (HDPE) and sponge-gourds (Luffa-Cylindrica) agroresidue composites. In Proceedings of the AIP Conference Proceedings 1664 (p. 1-5). USA: AIP Publishing LLC. https://doi.org/10.1063/1.4918430.

30. Machado, A. V., Moura, I., Duarte, F. M., Botelho, G., Nogueira, R., \& Brito, A. G. (2007). Evaluation of properties and biodeterioration potential of polyethylene and aliphatic polyester blends. International Polymer Processing, 22(5), 512-518. http://dx.doi.org/10.3139/217.2061.

31. Rosa, D. C., Guedes, C. G. F., \& Bardi, M. A. G. (2007). Evaluation of thermal, mechanical and morphological properties of PCL/CA and PCL/CA/PE-g-GMA blends. Polymer Testing, 26(2), 209-215. http://dx.doi.org/10.1016/j. polymertesting.2006.10.003.

32. Moura, I., Machado, A. V., Duarte, F. M., Botelho, G., \& Nogueira, R. (2008). Preparation of biodegradable materials by reactive extrusion. Materials Science Forum, 587-588, 520-524. http:// dx.doi.org/10.4028/www.scientific.net/MSF.587-588.520.

33. Silva, T. R. G. (2014). Influência da poli (E-caprolactona) e de copolímeros funcionalizados no desempenho de blendas com matriz de poli (Ácido-Lático) [Tese de doutorado). Universidade Federal de Campina Grande, Campina Grande.

34. Semba, T., Kitagawa, K., Ishiaku, U. S., Kotaki, M., \& Hamada, H. (2007). Effect of compounding procedure on mechanical properties and dispersed phase morphology of poly(lactic acid)/polycaprolactone blends containing peroxide. Journal of Applied Polymer Science, 103(2), 1066-1074. http://dx.doi. org/10.1002/app.25311.

35. Takasu, A., Oishi, Y., Lio, Y., Inai, Y., \& Hirabayashi, T. (2003). Synthesis of aliphatic polyesters by direct polyesterification of dicarboxylic acids with diols under mild conditions catalyzed by reusable rare-earth triflate. Macromolecules, 36(6), 17721774. http://dx.doi.org/10.1021/ma021462v.

36. Chevallier, C., Becquart, F., Majeste, J.-C., \& Taha, M. (2013). Solvent-free preparation, characterization, and properties of SEBS-g-polycarbonate copolymers. Designed Monomers and Polymers, 6(16), 564-577. http://dx.doi.org/10.1080/15 685551.2013.771309.

37. Araújo, J. P., Agrawal, P. A., \& Mélo, T. J. A. (2015). Blendas PLA/PEgAA: avaliação da reatividade entre os polímeros e da concentração de PEgAA nas propriedades e na morfologia. Revista Eletrônica de Materiais e Processos, 10(3), 118-127. Retrieved in 2018, March 15, from http://www2.ufcg.edu.br/ revista-remap/index.php/REMAP/article/view/475

38. Deblieck, R. A. C., Van Beek, D. J. M., Remerie, K., \& Ward, I. M. (2011). Failure mechanisms in polyolefines: the role of crazing, shear yielding and the entanglement network. Polymer, 52(14), 2979-2990. http://dx.doi.org/10.1016/j. polymer.2011.03.055.

39. Botlhoko, O. J., Ramontja, J., \& Ray, S. S. (2018). A new insight into morphological, thermal, and mechanical properties of melt-processed polylactide/poly( $\varepsilon$-caprolactone) blends. Polymer Degradation \& Stability, 154, 84-95. http://dx.doi. org/10.1016/j.polymdegradstab.2018.05.025.

40. França, D. C., Morais, D. D., Bezerra, E. B., Araújo, E. M., \& Wellen, R. M. R. (2018). Photodegradation mechanisms on poly(E-caprolactone) (PCL). Materials Research, 21(5), 1-8. http://dx.doi.org/10.1590/1980-5373-mr-2017-0837.

41. Guimarães, M. J. O. C., Rocha, M. C. G., \& Coutinho, F. M. B. (2002). Polietileno de alta densidade tenacificado com elastômero metalocênico: 1. Propriedades mecânicas e características morfológicas. Polímeros: Ciência e Tecnologia, 12(2), 76-84. http://dx.doi.org/10.1590/S0104-14282002000200006.

42. Roeder, J., Oliveira, R. V. B., Gonçalves, M. C., Soldi, V., \& Pires, A. T. N. (2002). Polypropylene/polyamide-6 blends: influence of compatibilizing agent on interface domains. Polymer Testing, 21(7), 815-821. http://dx.doi.org/10.1016/ S0142-9418(02)00016-8.

43. Bucknall, C. B., \& Paul, D. R. (2009). Notched impact behavior of polymer blends: Part 1: new model for particle size dependence. Polymer, 50(23), 5539-5548. http://dx.doi. org/10.1016/j.polymer.2009.09.059. 
44. Liu, H., Song, W., Chen, F., Guo, L., \& Zhang, J. (2011). Interaction of microstructure and interfacial adhesion on Impact Performance of Polylactide (PLA) ternary blends. Macromolecules, 44(6), 1513-1522. http://dx.doi.org/10.1021/ ma1026934.

45. Plochocki, A. P., Dagli, S. S., \& Andrews, R. D. (1990). The interface in binary mixtures of polymers containing a corresponding block copolymer: Effects of industrial mixing processes and of coalescence. Polymer Engineering and Science, 30(12), 741-752. http://dx.doi.org/10.1002/pen.760301207.

46. Pracella, M. (2016). Modification of polymer properties. Oxford: Elsevier Science.

47. Sánchez, A., Rosales, C., Laredo, E., Müller, A. J., \& Pracella, M. (2001). Compatibility studies in binary blends of PA6 and ULDPE-graft-DEM. Macromolecular Chemistry and Physics, 202(11), 2461-2478. http://dx.doi.org/10.1002/15213935(20010701)202:11<2461::AID-MACP2461>3.0.CO;2-1.
48. Barcellos, I. O. (1998). Estudo de blendas poliméricas e hidrogéis com aplicações na área biomédica [Tese de doutorado). Universidade Federal de Santa Catarina, Florianópolis.

49. Zinadini, S., Zinatizadeh, A. A., Rahimi, M., Vatanpour, V., \& Zangeneh, H. (2014). Preparation of a novel antifouling mixed matrix PES membrane by embedding graphene oxide nanoplates. Journal of Membrane Science, 453(1), 292-301. http://dx.doi.org/10.1016/j.memsci.2013.10.070.

50. Rahimi, M., Zinadini, S., Zinatizadeh, A. A., Vatanpour, V., Rajabi, L., Rahimi, Z. (2016). Hydrophilic goethite nanoparticle as a novel antifouling agent in fabrication of nanocomposite polyethersulfone membrane. Journal of Applied Polymer Science, 133(26), 1-13. http://dx.doi.org/10.1002/app.43592.

Received: Mar. 20, 2018

Revised: Jan. 06, 2019

Accepted: Feb. 20, 2019 
Appendix 1. Datasheets.

\section{STFS I'm Folha de Dados green Rests\$o $6($ Ses:2014)}

\section{Polietileno de Alta Densidade SHC7260}

\section{Descrição:}

A resina SHC7260 é um polietileno de alta densidade desenvolvido para o segmento de injeção. possui densidade, dureza e rigidez elevados. Sua distribuição estreita de massa molar resulta em baixa tendência à deformação.

Este grade tem conteúdo mínimo de fonte renovável de $94 \%$, deberminado conforme ASTM D6866.

\section{Aplicações:}

Caíxas para pescado e hortifrutículas, caixas para uso industrial e uso geral;

Capacetes;

Assentos sanitários:

Utilidades domésticas;

Brinquedos;

Tampas;

Paletes.

Embalagens rigidas para cosméticos e produtos farmacėuticos (cumpre com USP 37 ).

\section{Processo:}

Moldagem por Injeção

\section{Propriedades de Controle:}

\begin{tabular}{|l|c|c|c|}
\hline & Método ASTM & Unidades & Valores \\
\hline Indice de fluidez $(190 / 2,16)$ & D 1238 & $\mathrm{~g} / 10 \mathrm{~min}$ & 7,2 \\
\hline Densidade & D 792 & $\mathrm{~g} / \mathrm{cm}^{3}$ & 0,959 \\
\hline
\end{tabular}

\section{Propriedades Típicas:}

Propriedades de Referência de Placa a

\begin{tabular}{|l|c|c|c|}
\hline & Método ASTM & Unidades & Valores \\
\hline Resistência à Tração no Escoamento & D 638 & MPa & 30 \\
\hline Alongamento no Escoamento & D 638 & $\%$ & 7,5 \\
\hline Módulo de Flexão Secante a 1\% & D 790 & MPa & 1350 \\
\hline Dureza Shore D & D 2240 & - & 64 \\
\hline Resistência ao Impacto Izod & D 256 & $\mathrm{J} / \mathrm{m}$ & 35 \\
\hline $\begin{array}{l}\text { Resistência à Quebra sob Tensão } \\
\text { Ambiental }\end{array}$ & D 1693 & h/F50 & $<4$ \\
\hline $\begin{array}{l}\text { Temperatura de Amolecimento Vicat } \\
\text { a } 10 \mathrm{~N}\end{array}$ & D 1525 & ${ }^{\circ} \mathrm{C}$ & 126 \\
\hline $\begin{array}{l}\text { Temperatura de Deflexão Térmica a } \\
0,455 \mathrm{MPa}\end{array}$ & D 648 & ${ }^{\circ} \mathrm{C}$ & 76 \\
\hline
\end{tabular}

(a) Placa moldada por compressio pelo Merodo ASTM D 4703.

(b) Condiğes: $100 \%$ Igepd, placa de $2 \mathrm{~mm}$, com erealle de 0,3 mm, $50^{\circ} \mathrm{C}$

\section{Observaçoes Finais:}

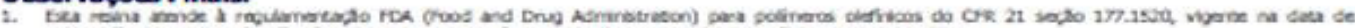

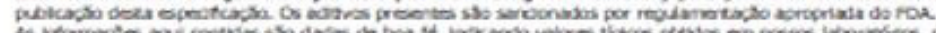

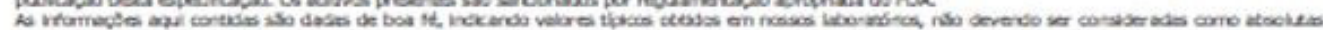

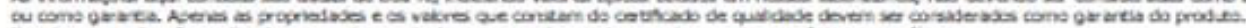

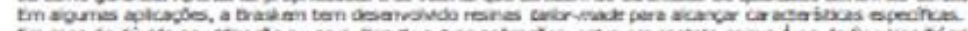

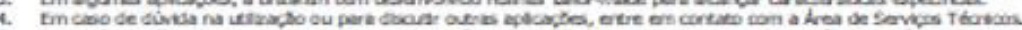

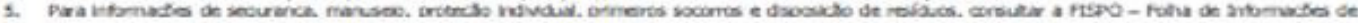

Figure A1. Datasheets - HDPE. 


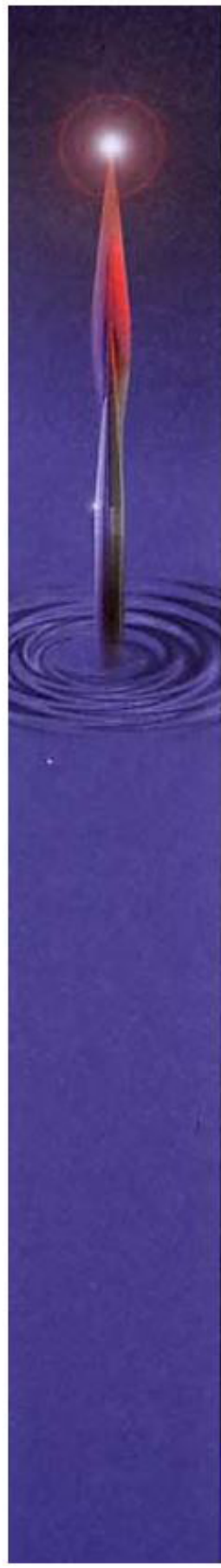

'Typical Physical Properties of CAPA 'Thermoplastics'

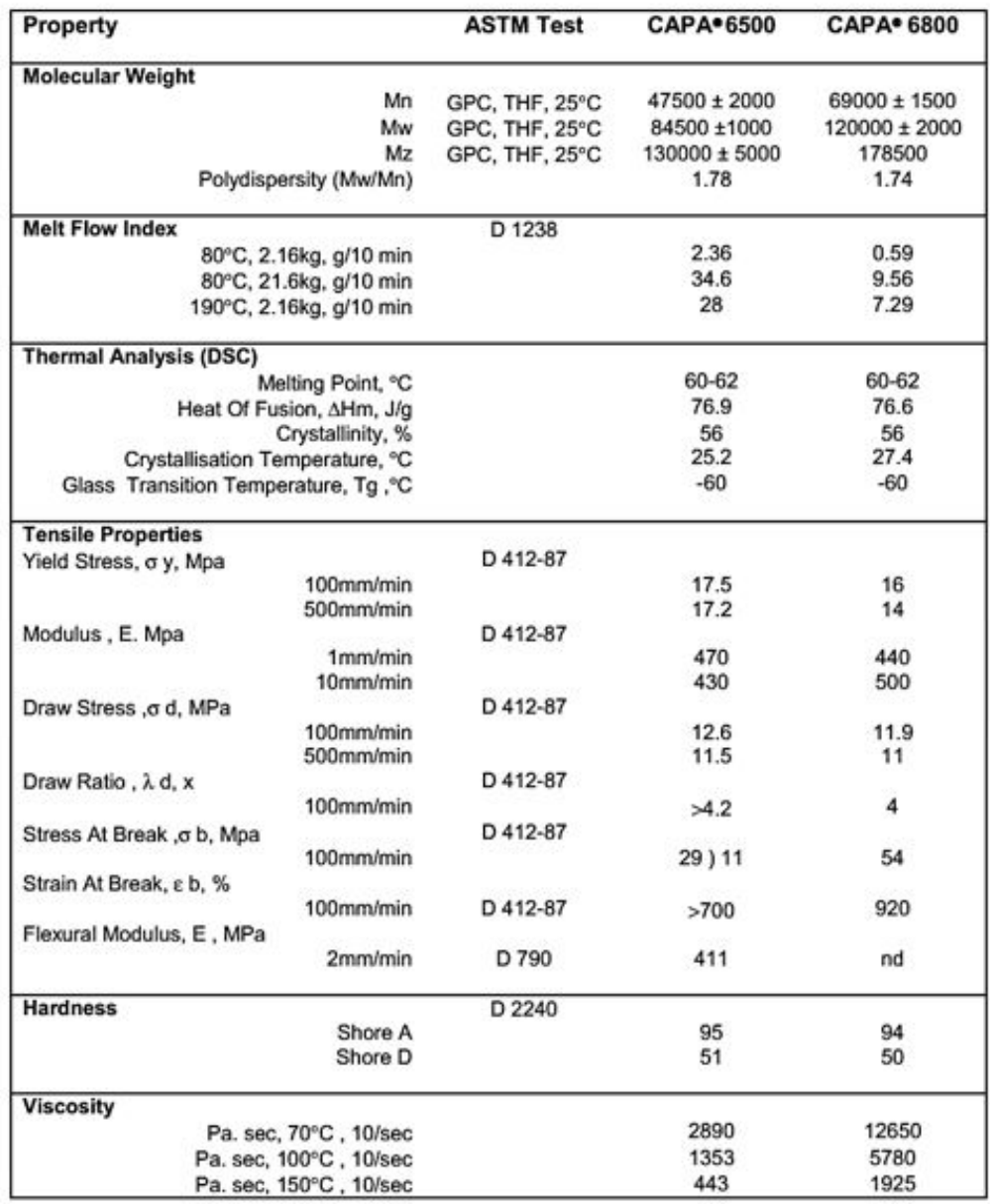

CAPA $^{\circledR} 6500$ is a 50000 molecular weight homopolymer which, because of its relatively low viscosity and melting point has found considerable use in the manufacture of orthopaedic casts, as an adhesive and is particularly suited for making injection moulded parts.

CAPA $^{\circledR} 6800$ is a higher viscosity material having a molecular weight of 80000 , and is more suited to the manufacture of films and bottles.

Figure A2. Datasheets - PCL. 


\section{POLYBOND ${ }^{\circledR} 3029$ \\ Polymer Modifier}

POLYBOND ${ }^{\oplus} 3029$ is a maleic anhydride modified high density polyethylene.

\section{CAS Number 25213-02-9}

Typical Physical Properties of POLYBOND 3029

\begin{tabular}{|l|l|l|}
\hline Property & Typical Valuc & Test Based On \\
\hline Appearance & Off-white Pellet & Visual \\
\hline Melt Flow Rate @ $190^{\circ} \mathrm{C}, 2.16 \mathrm{Kg}$ & $4.0 \mathrm{~g} / 10 \mathrm{~min}$ & ASTM D-1238 \\
\hline Maleic Anhydride Content & Very High & ASTM D-6047 \\
\hline Density @ $23^{\circ} \mathrm{C}$ & $0.95 \mathrm{~g} / \mathrm{cm}^{3}$ & ASTM D-792 \\
\hline Bulk Density & $0.6 \mathrm{~g} / \mathrm{cm}^{3}$ & ASTM D-1895B \\
\hline Melting Point & $130^{\circ} \mathrm{C}$ & DSC \\
\hline
\end{tabular}

- Very High = Maleic Anhydride Content typically in the rango of 1.5 to $1.7 \%$.

\section{Applications}

- High functionality making this product ideal for use as a coupling agent in wood polyethylene composites where reduced water uptake and higher strength properties are required

- Coupling agent for glass-filled polyethylene providing improved physical properties including strength

- Compatibilizer for polyethylene/polyamide blends giving enhanced hydrolytic stability and strength properties

- Coupling agent for polyethylene composites with high mineral filler levels offering improved strength and impact properties

- Coupling agent and process aid for halogen-free, flame retardant (HFFR) wire \& cable compounds giving improved dispersion of flame retardant along with improved mechanical properties

\section{Food Contact}

For details please contact Addivant ${ }^{\text {TM }}$ Regulatory Affairs

\section{Regulatory Status}

The components of POLYBOND ${ }^{\oplus} 3029$ are listed on USA TSCA inventory. For information on other inventory listings, see Section 15 (Regulatory Information) of the MSDS for POLYBOND 3029.

\section{Storage \& Handling Precautions \\ Keep POLYBOND 3029 dry prior to processing. Loss of anhydride functionality may occur due to conversion to acid groups by reaction with atmospheric moisture. Tie liners of open boxes when not in use to prevent exposure to moisture. If exposure occurs, POLYBOND ${ }^{\oplus} 3029$ can be dried in a hopper dryer or oven for three hours at $95-100^{\circ} \mathrm{C}$ to remove moisture. A slight pungent odor is normal during processing of POLYBOND ${ }^{\oplus} 3029$. Purge equipment with polyethylene before and after running POLYBOND ${ }^{\oplus} 3029$.}

\footnotetext{
The information contained herein relates to a specific Addivant ${ }^{\mathrm{TM}}$ product and its use, and is based on information available as of the date hereot. Additional Irformaton relasing to the product can be obtained from the pertinent Material Safoty Dxa Sheets. Nothing in this Technical Dara Sheet shall be comstrued to modify any of Addlivant ${ }^{\text {TM }}$ standard terms and condis ons of sale under which the product is sold by Addivant ${ }^{\text {TM }}$. NOTHRG iN THIS TECHMCAL DATA SHEET SHALL BE CONSTRUED TO CONSTTUTE A REPRESENTATION OR WARRANTY, EXPRESSOR IMPLIED, REGARDING THIS TECHMCAL DATA SHEET SHALL BE CONSTRUED TO CONS TTUTE A REP RESENTATION OR WARRANTY, EXPRESSOR IMPLED, REGARDING SUCH REPRESENTATIONS AND WARRANTES AFE HEREBY EXPRESSLY DISCLAIMED. Nothing containod hereln shall constitute permisslon or recommendation to practice any intellectual property without the permission of the owner.

Addivant ${ }^{\text {TM }}$ is a trademark of Addivant USA, LLC or one of its atriliates.

Copyright $Q 2013$ Addivant USA, LLC. Al rights reserved.
}

Figure A3. Datasheets - PEgMA. 
Appendix 2 . DSC Results - Tables.

Table A1. DSC data for Bio-PE collected during the cooling - Melt Crystallization Event.

\begin{tabular}{lcccccccc}
\hline & \multicolumn{10}{c}{ First Peak-BioPE } \\
\hline $\begin{array}{c}\text { Compounds } \\
(\mathbf{\%})\end{array}$ & $\begin{array}{c}T_{\mathbf{0 . 1 \%}} \\
\left({ }^{\circ} \mathbf{C}\right)\end{array}$ & $\begin{array}{c}T_{\mathbf{5 0} \%} \\
\left({ }^{\circ} \mathbf{C}\right)\end{array}$ & $\begin{array}{c}T_{99.9 \%} \\
\left({ }^{\circ} \mathbf{C}\right)\end{array}$ & $\begin{array}{c}T_{m p} \\
\left({ }^{\circ} \mathbf{C}\right)\end{array}$ & $\begin{array}{c}c_{\max } \\
\left(\mathbf{m i n}^{-1}\right)\end{array}$ & $\begin{array}{c}t^{1 / 2} \\
(\mathbf{m i n})\end{array}$ & $\begin{array}{c}\Delta \mathbf{H}_{m} \\
(\mathbf{J} / \mathbf{g})\end{array}$ & $\begin{array}{c}\mathbf{X}_{c} \\
(\%)\end{array}$ \\
\hline Bio-PE & 119.19 & 115.31 & 106.04 & $115.37-$ & 1.7756 & 0.49 & 37.88 & 12.93 \\
PCL & - & - & - & - & - & - & - & - \\
Bio-PE/PCL (70/30) & 119.70 & 116.66 & 107.52 & 116.90 & 2.5037 & 0.39 & 42.49 & 14.50 \\
Bio-PE/PCL (80/20) & 119.46 & 115.91 & 107.46 & 116.03 & 2.1497 & 0.45 & 38.24 & 13.05 \\
Bio-PE/PCL (90/10) & 119.38 & 116.07 & 107.12 & 116.15 & 2.2896 & 0.43 & 49.55 & 16.91 \\
Bio-PE/PCL/PEgMA (70/30/10Pcr) & 119.35 & 116.13 & 107.52 & 116.42 & 2.3361 & 0.41 & 43.27 & 14.77 \\
Bio-PE/PCL/PEgMA (80/20/10Pcr) & 119.39 & 116.59 & 107.34 & 116.84 & 2.2740 & 0.37 & 43.86 & 14.97 \\
Bio-PE/PCL/PEgMA (90/10/10Pcr) & 119.36 & 116.03 & 105.39 & 116.49 & 1.7684 & 0.42 & 46.38 & 15.83 \\
\hline
\end{tabular}

Table A2. DSC data for PCL collected during the cooling - Melt Crystallization Event.

\begin{tabular}{|c|c|c|c|c|c|c|c|c|}
\hline \multicolumn{9}{|c|}{ Second Peak-PCL } \\
\hline $\begin{array}{c}\text { Compounds } \\
(\%)\end{array}$ & $\begin{array}{l}T_{0.1 \%} \\
\left({ }^{\circ} \mathrm{C}\right)\end{array}$ & $\begin{array}{l}T_{50 \%} \\
\left({ }^{\circ} \mathrm{C}\right)\end{array}$ & $\begin{array}{l}T_{99.9 \%} \\
\left({ }^{\circ} \mathrm{C}\right)\end{array}$ & $\begin{array}{c}T_{m p} \\
\left({ }^{\circ} \mathbf{C}\right)\end{array}$ & $\begin{array}{c}c_{\max } \\
\left(\min ^{-1}\right)\end{array}$ & $\begin{array}{c}t^{1 / 2} \\
(\mathrm{~min})\end{array}$ & $\begin{array}{l}\Delta \mathbf{H}_{m} \\
(\mathbf{J} / \mathbf{g})\end{array}$ & $\begin{array}{c}\mathbf{X}_{c} \\
(\%)\end{array}$ \\
\hline Bio-PE & - & - & - & - & - & - & - & - \\
\hline PCL & 34.42 & 29.79 & 23.79 & 29.77 & 2.1030 & 0.49 & 21.58 & 15.47 \\
\hline Bio-PE/PCL (70/30) & 42.48 & 37.22 & 32.91 & 36.85 & 2.2325 & 0.54 & 11.02 & 7.90 \\
\hline Bio-PE/PCL (80/20) & 43.79 & 38.80 & 34.48 & - & 1.8600 & 0.50 & 8.05 & 5.77 \\
\hline Bio-PE/PCL (90/10) & 42.61 & 38.75 & 35.18 & 37.96 & 2.0444 & 0.39 & 6.62 & 4.75 \\
\hline Bio-PE/PCL/PEgMA (70/30/10Pcr) & 44.42 & 39.47 & 34.16 & 39.86 & 1.6427 & 0.50 & 8.95 & 6.42 \\
\hline Bio-PE/PCL/PEgMA (80/20/10Pcr) & 45.17 & 41.27 & 37.24 & 41.39 & 2.1896 & 0.39 & 6.99 & 5.01 \\
\hline Bio-PE/PCL/PEgMA (90/10/10Pcr) & 44.80 & 41.64 & 38.47 & 41.79 & 2.5397 & 0.32 & 5.33 & 3.82 \\
\hline
\end{tabular}

Table A3. DSC data for PCL collected during the second heating - Fusion Event.

\begin{tabular}{|c|c|c|c|c|c|c|c|c|}
\hline \multicolumn{9}{|c|}{ FirstPeak-PCL } \\
\hline $\begin{array}{c}\text { Compounds } \\
(\%)\end{array}$ & $\begin{array}{l}T_{0.1 \%} \\
\left({ }^{\circ} \mathrm{C}\right)\end{array}$ & $\begin{array}{l}T_{50 \%} \\
\left({ }^{\circ} \mathrm{C}\right)\end{array}$ & $\begin{array}{l}T_{99.9 \%} \\
\left({ }^{\circ} \mathrm{C}\right)\end{array}$ & $\begin{array}{c}T_{m p} \\
\left({ }^{\circ} \mathbf{C}\right)\end{array}$ & $\begin{array}{c}c_{\max } \\
\left(\min ^{-1}\right)\end{array}$ & (min) & $\begin{array}{l}\Delta \mathbf{H}_{m} \\
(\mathbf{J} / \mathbf{g})\end{array}$ & $\begin{array}{c}\mathbf{X}_{c} \\
(\%)\end{array}$ \\
\hline Bio-PE & - & - & - & - & - & - & - & - \\
\hline PCL & 46.57 & 56.78 & 62.05 & 57.19 & 1.7776 & 1.04 & 19.74 & 14.15 \\
\hline Bio-PE/PCL (70/30) & 47.87 & 55.08 & 57.93 & 55.65 & 2.9497 & 0.73 & 11.03 & 7.90 \\
\hline Bio-PE/PCL (80/20) & 48.32 & 55.39 & 58.47 & 56.05 & 2.6811 & 0.71 & 9.81 & 7.03 \\
\hline Bio-PE/PCL (90/10) & 51.75 & 55.63 & 58.11 & 56.03 & 3.1103 & 0.39 & 9.26 & 6.63 \\
\hline Bio-PE/PCL/PEgMA (70/30/10Pcr) & 46.36 & 55.14 & 59.13 & 56.02 & 2.4021 & 0.89 & 11.62 & 8.33 \\
\hline Bio-PE/PCL/PEgMA (80/20/10Pcr) & 48.63 & 55.33 & 58.52 & 56.19 & 2.5409 & 0.67 & 10.32 & 7.40 \\
\hline Bio-PE/PCL/PEgMA (90/10/10Pcr) & 51.14 & 55.61 & 58.02 & 56.26 & 2.8503 & 0.45 & 7.08 & 5.07 \\
\hline
\end{tabular}

Table A4. DSC data for Bio-PE collected during the second heating - Fusion Event.

\begin{tabular}{lcccccccc}
\hline & \multicolumn{9}{c}{ Second Peak-BioPE } \\
\hline $\begin{array}{c}\text { Compounds } \\
(\mathbf{\% )}\end{array}$ & $\begin{array}{c}T_{\mathbf{0 . 1 \%}} \\
\left({ }^{\circ} \mathbf{C}\right)\end{array}$ & $\begin{array}{c}T_{\mathbf{5 0} \%} \\
\left({ }^{\circ} \mathbf{C}\right)\end{array}$ & $\begin{array}{c}T_{99.9 \%} \\
\left({ }^{\circ} \mathbf{C}\right)\end{array}$ & $\begin{array}{c}T_{m p} \\
\left({ }^{\circ} \mathbf{C}\right)\end{array}$ & $\begin{array}{c}c_{\max } \\
\left(\mathbf{m i n}^{-1}\right)\end{array}$ & $\begin{array}{c}t^{1 / 2} \\
(\mathbf{m i n})\end{array}$ & $\begin{array}{c}\Delta \mathbf{H}_{m} \\
(\mathbf{J} / \mathbf{g})\end{array}$ & $\begin{array}{c}\mathbf{X}_{c} \\
(\%)\end{array}$ \\
\hline Bio-PE & 106.41 & 131.18 & 138.46 & 133.47 & 1.0994 & 2.53 & 41.46 & 14.15 \\
PCL & - & - & - & - & - & - & - & - \\
Bio-PE/PCL (70/30) & 110.55 & 129.88 & 135.55 & 131.76 & 1.5131 & 1.97 & 47.05 & 16.06 \\
Bio-PE/PCL (80/20) & 110.98 & 130.54 & 136.80 & 132.46 & 1.2590 & 2.00 & 41.28 & 14.09 \\
Bio-PE/PCL (90/10) & 110.06 & 130.96 & 137.04 & 133.05 & 1.4486 & 2.13 & 53.58 & 18.29 \\
Bio-PE/PCL/PEgMA (70/30/10Pcr) & 110.25 & 129.82 & 135.87 & 131.86 & 1.4086 & 1.99 & 47.68 & 16.27 \\
Bio-PE/PCL/PEgMA (80/20/10Pcr) & 106.97 & 129.75 & 136.01 & 131.77 & 1.2183 & 2.32 & 48.33 & 16.50 \\
Bio-PE/PCL/PEgMA (90/10/10Pcr) & 106.98 & 130.72 & 137.58 & 132.88 & 1.0978 & 2.41 & 49.52 & 16.90 \\
\hline
\end{tabular}


Appendix 3. DSC parameters Figures A4-A11.

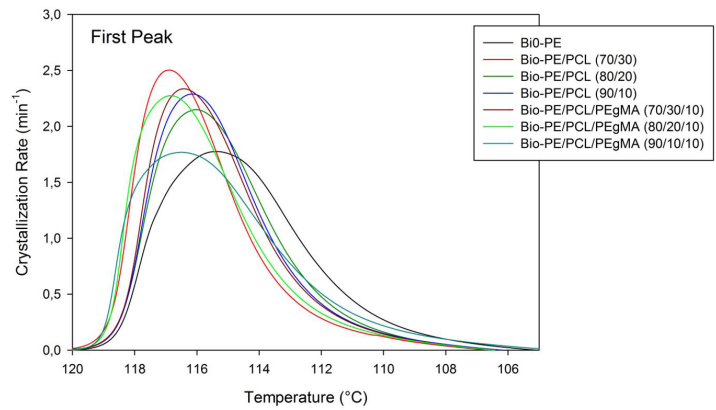

Figure A4. Crystallization Rate of Bio-PE in the investigated compounds.

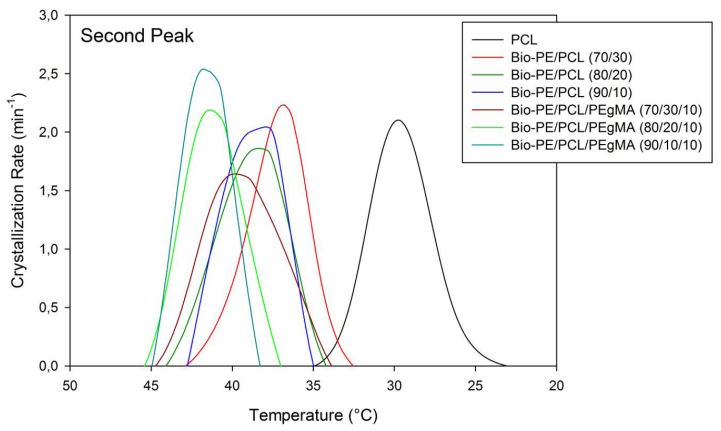

Figure A5. Crystallization Rate of PCL in the investigated compounds.

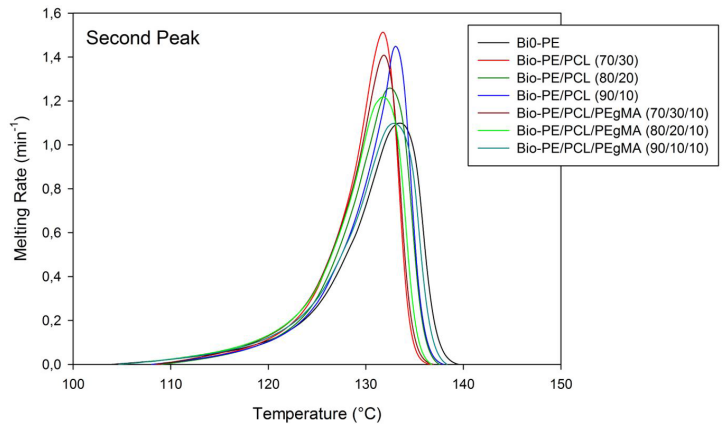

Figure A6. Melting Rate of Bio-PE in the investigated compounds.

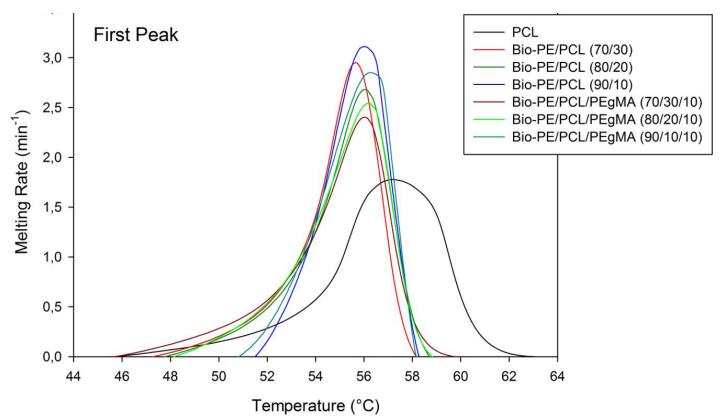

Figure A7. Melting Rate of PCL in the investigated compounds.

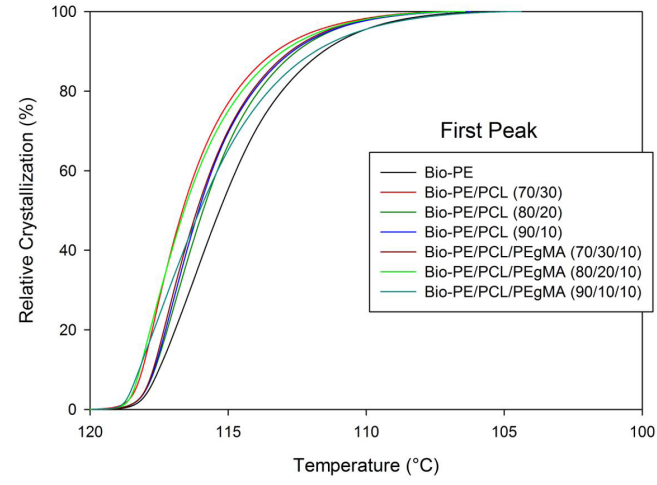

Figure A8. Relative Crystallinity of Bio-PE in the investigated compounds.

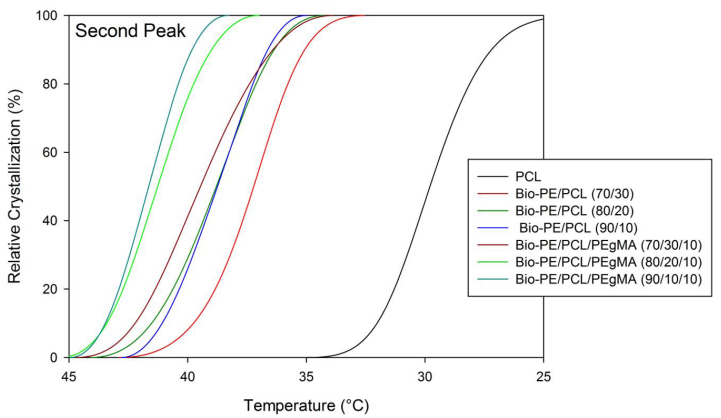

Figure A9. Relative Crystallinity of PCL in the investigated compounds.

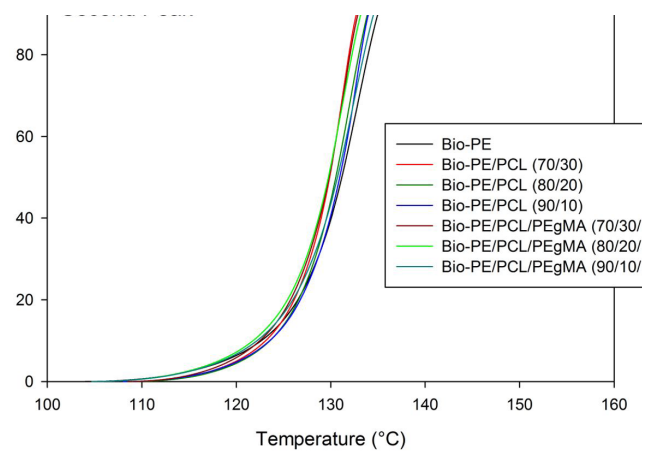

Figure A10. Molten Fraction of Bio-PE in the investigated compounds.

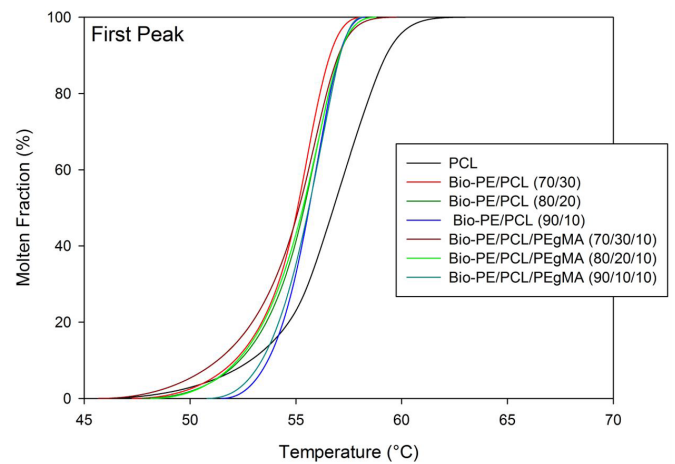

Figure A11. Molten Fraction of PCL in the investigated compounds. 
Appendix 4. Contact angle average data with the standard deviation.

Table A5. Average contact angle with its respective standard deviation.

\begin{tabular}{lc}
\hline \multicolumn{1}{c}{ Composition } & Contact angle \\
\hline Bio-PE (100) & $71.5 \pm 0.7$ \\
Bio-PE/PCL (90/10) & $60.3 \pm 0.7$ \\
Bio-PE/PCL (80/20) & $60.7 \pm 1.1$ \\
Bio-PE/PCL (70/30) & $75.3 \pm 1.9$ \\
Bio-PE/PCL/PEgMA (90/10/10) & $68.8 \pm 1.2$ \\
Bio-PE/PCL/PEgMA (80/20/10) & $69.8 \pm 0.8$ \\
Bio-PE/PCL/PEgMA (70/30/10) & $77.8 \pm 2.0$ \\
PCL (100) & $61.2 \pm 1.1$ \\
\hline
\end{tabular}

